\title{
Neural transplantation in hypogonadal (hpg) mice - physiology and neurobiology
}

\author{
Harry Charlton \\ Department of Human Anatomy and Genetics, South Parks Road, Oxford, OX1 3QX, UK \\ Correspondence should be addressed to Harry Charlton; Email: harry.charlton@anat.ox.ac.uk
}

\begin{abstract}
The hypogonadal (hpg) mouse mutant has a deletion in the region encoding the hypothalamic gonadotrophic hormone-releasing hormone decapeptide. As a consequence pituitary gonadotrophic hormone synthesis and release is severely curtailed and there is little or no post-natal gonadal development. Grafts of late fetal/early neonatal brain tissue containing the decapeptide-producing neurones into the third ventricle of hpg mice result, in a majority of animals, in a near normalisation of pituitary function with full spermatogenesis in male mice and full follicular and uterine development in females. The vast majority of positive responding females with vaginal opening and uterus growth show no evidence of spontaneous oestrous cycles, ovulation or corpora lutea. These female mice mate with normal males with many of them demonstrating reflex ovulation. In both male and female mutants with successful grafts there is an absence of gonadal steroid negative feedback upon the synthesis and secretion of pituitary gonadotrophic hormones. The releasing factor axon terminals from grafts within the third ventricle identified by immunohistochemical methods are targeted specifically to the median eminence. There is evidence for host innervation of grafts, but how specific this is for the control of gonadotrophic hormone-releasing hormone cell bodies remains to be elucidated.
\end{abstract}

Reproduction (2004) 127 3-12

\section{Introduction}

The hypothalamic decapeptide gonadotrophic hormonereleasing hormone $(\mathrm{GnRH})$ is central to the regulation of brain-pituitary-gonadal interrelationships in vertebrates (Everett 1994). Release of the hormone into the portal vessels leading from the hypothalamus to the pituitary gland results in the synthesis and secretion of the pituitary gonadotrophic hormones, luteinising hormone (LH) and follicle-stimulating hormone (FSH). These, in turn, stimulate testicular and ovarian function with feedback control from the gonads acting at the pituitary, the GnRH neurones themselves, or at central nervous system (CNS) sites controlling these neurones. With the use of antibodies raised against $\mathrm{GnRH}$ the preoptic area of the brain has been identified as the major site of $\mathrm{GnRH}$ neurones (Silverman et al. 1994). These neurones are actually formed within the nasal placode and migrate into the anterior hypothalamus via the cribriform plate of the ethmoid bone (Wray 2002).

A great deal of research has dealt with the neuroanatomical input into GnRH neurones and how their function can be regulated by steroid and other molecules from the peripheral circulation or locally derived factors within the brain itself in the control of spermatogenesis in the male and ovarian function in the female (Herbison 1998, Ebling \& Cronin 2000). The use of immortalised GnRH cell lines has also been central to our understanding of mechanisms controlling the synthesis and secretion of the decapeptide (Weiner et al. 1992). The detective work leading up to the isolation and chemical synthesis of $\mathrm{GnRH}$ involved the use of a variety of techniques including electrical stimulation, electrolytic lesioning, surgical ablation and the transplantation of endocrine tissues (Harris 1972). A powerful demonstration that $\mathrm{GnRH}$ is an essential component in controlling brain-pituitary-gonadal interrelationships (see Fig. 1) would be to disrupt the gene encoding this hormone, a technique now commonly used in gene knockout technology in mice, and to follow the physiological consequences. Nature sometimes does the experiment for us and the discovery 25 years ago of the hypogonadal (hpg) mouse in which there is a failure of post-natal gonadal development provided us with a GnRH-deficient model (see Fig. 2). The initial diagnosis of the defect in these mutants depended upon hormone assays which demonstrated that the hypothalamus contained no immunoreactive $\mathrm{GnRH}$, with a consequent depletion in pituitary LH and FSH (Cattanach et al. 1977). 


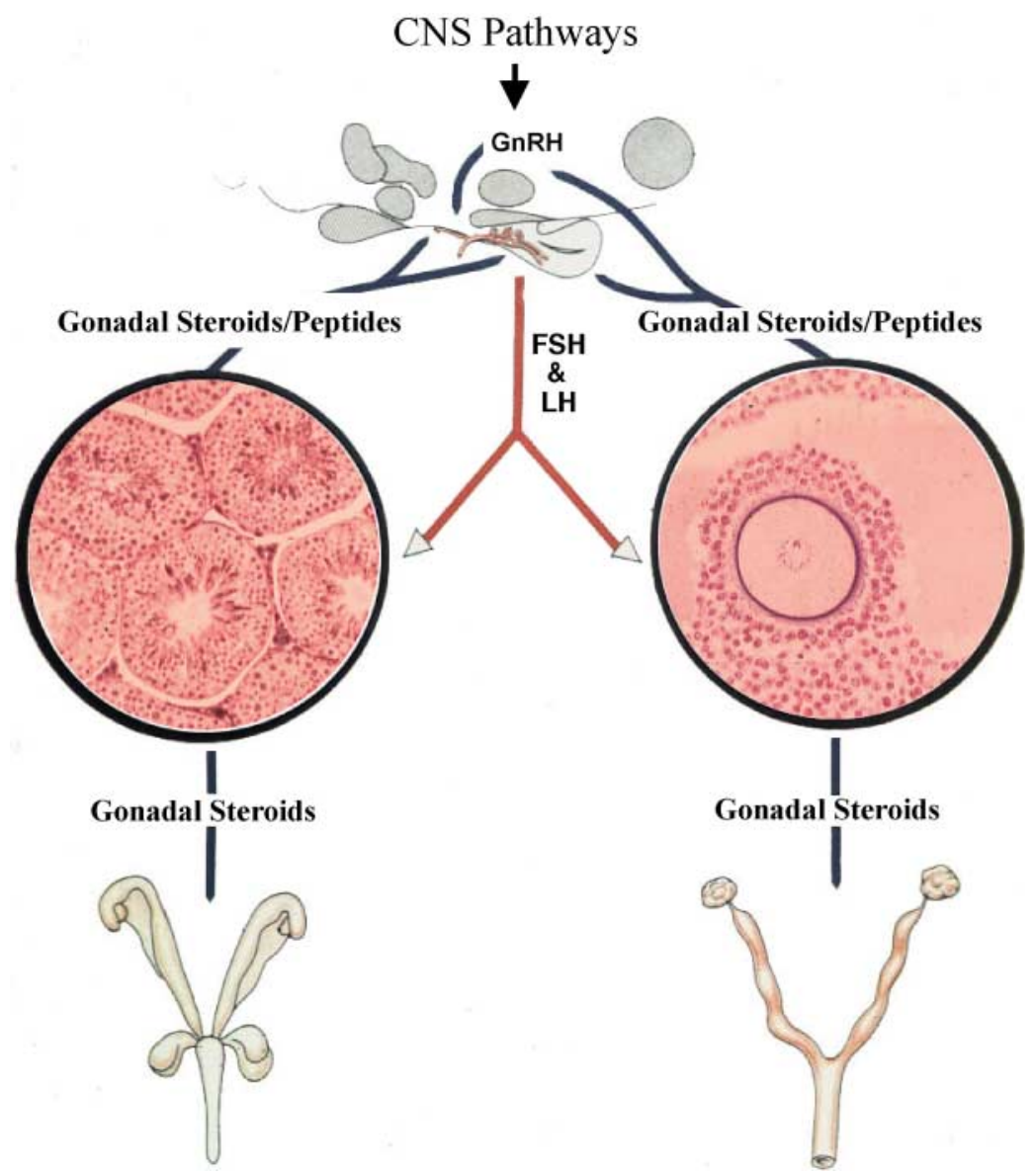

Figure 1 Diagram representing brain-pituitary-gonadal interrelationships. GnRH secretion from the median eminence to the pituitary gland is controlled by higher centres in the brain. The decapeptide stimulates synthesis and secretion of $\mathrm{LH}$ and FSH by the pituitary gland. These two hormones activate the gonads which, in turn, secrete steroid and peptide hormones which exert feedback control at the level of both the pituitary and the CNS.
This was confirmed in tissue sections of the median eminence in which no GnRH immunoreactive cells or fibres were found in hpg mice (see Fig. 3). Injections of GnRH stimulated pituitary $\mathrm{LH}$ and $\mathrm{FSH}$ synthesis and secretion and activation of the gonads (Charlton et al. 1983).
The GnRH precursor has been shown to consist of a 23-amino acid signal peptide, the decapeptide $\mathrm{GnRH}$ itself which is linked by Gly-Lys-Arg to a 56-amino acid sequence which has been called GnRH-associated peptide (GAP). Analysis of the DNA from $h p g$ mice revealed a

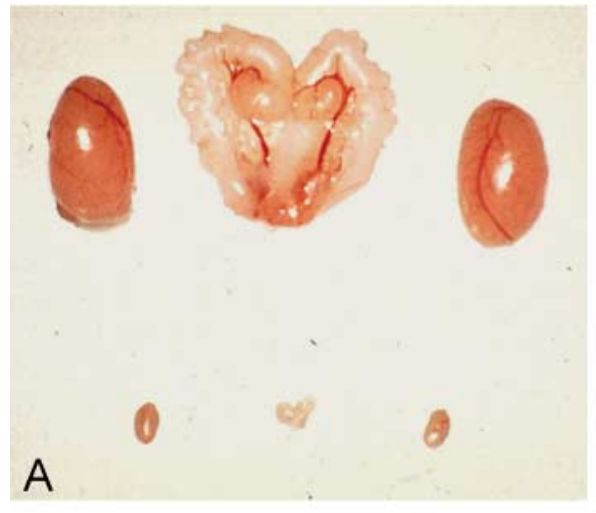

B

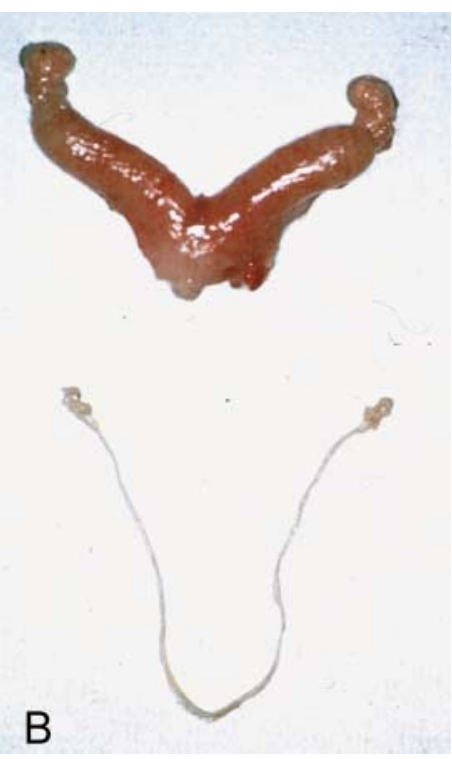

Figure 2 Photographs of the gonads and accessory sexual tissue of normal and hpg mice. (A) The extremely small testes of the hpg male are shown (below) compared with a litter mate control (above). The atrophic nature of the seminal vesicles is also an indication that little or no testosterone is secreted by the mutant testis. (B) The ovaries and uterus of normal (above) and hpg (below) females are shown. Note the extremely small ovaries and the thread-like uterus. 

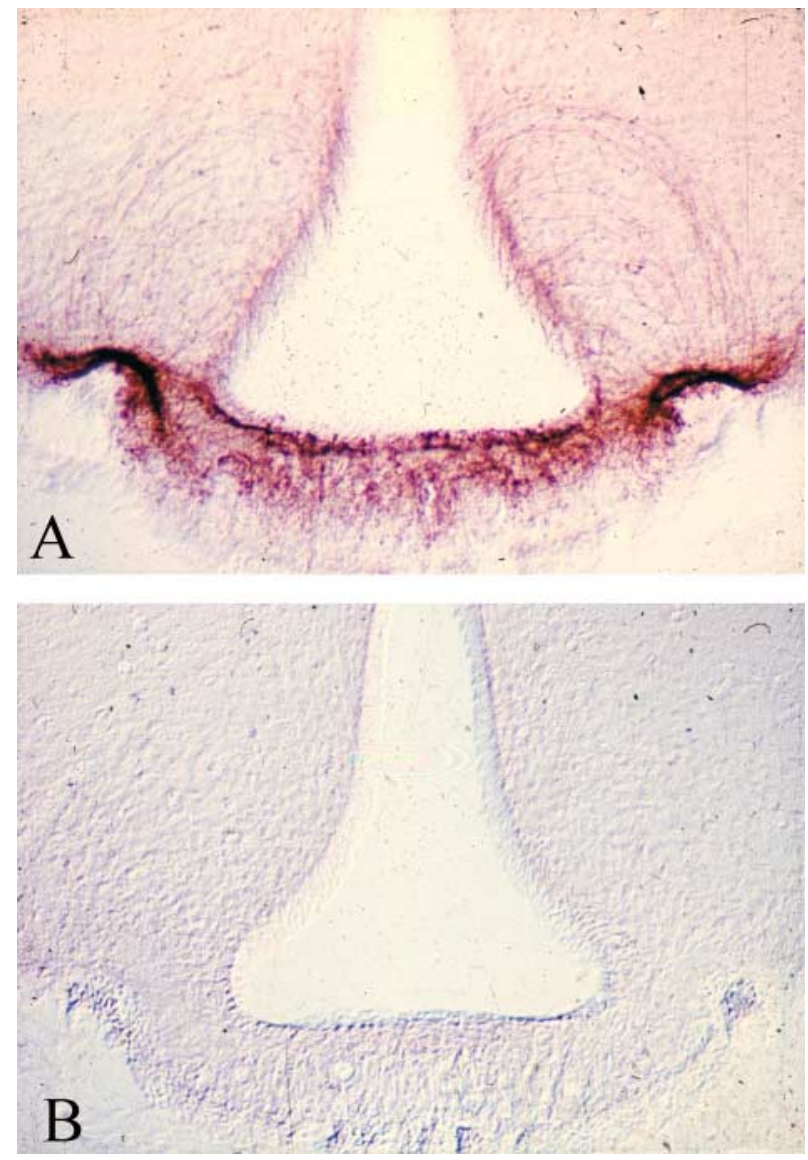

Figure $3 \mathrm{GnRH}$ immunostaining in coronal sections through the median eminence of normal and hpg mice. The intense staining for $\mathrm{GnRH}$ in the nerve terminals at the median eminence of a normal mouse (A) as compared with the total absence of any immunoreactive product in the hpg mutant (B). The space above the median eminence is the third ventricle. massive $33.5 \mathrm{~kb}$ deletion beginning distal to the 11 th amino acid in GAP. The partially deleted gene was shown to be transcriptionally active, but antigens corresponding to the precursor protein could not be detected immunocytochemically (Mason et al. 1986a).

Subsequent technological advances allowed the production of transgenic hpg mutants that contained copies of the normal GnRH gene. This resulted in full restoration of gonadal activity in both sexes, a powerful demonstration of the strategic importance of $\mathrm{GnRH}$ in reproduction (Mason et al. 1986b). Another method of giving back this hypothalamic factor was to transplant preoptic area (POA) neural tissue (the region of the brain rich in $\mathrm{GnRH}$ cell bodies) into the third ventricle of adult hpg mice.

The technique of transplantation is very simple. Using late fetal/early neonatal donors, a block of tissue is dissected from the base of the brain just anterior to the optic chiasm which includes both preoptic areas. Without further disruption of the tissue it is taken up in a plungerin-needle syringe and, under stereotaxic surgery, ejected into the third ventricle in the mid-line (see Fig. 4). This review will describe the physiological effects of these POA grafts and discuss factors determining their survival and neurobiological interactions.

\section{Physiology \\ Pituitary and gonadal activation}

The first report of the physiological action of POA grafts in hpg mice was that of Krieger et al. (1982) in which engrafted male hpg mutants exhibited increased pituitary and plasma gonadotrophin concentrations, testicular growth and evidence of full spermatogenesis (see Fig. 5A and B). In all animals in which the gonads were stimulated,
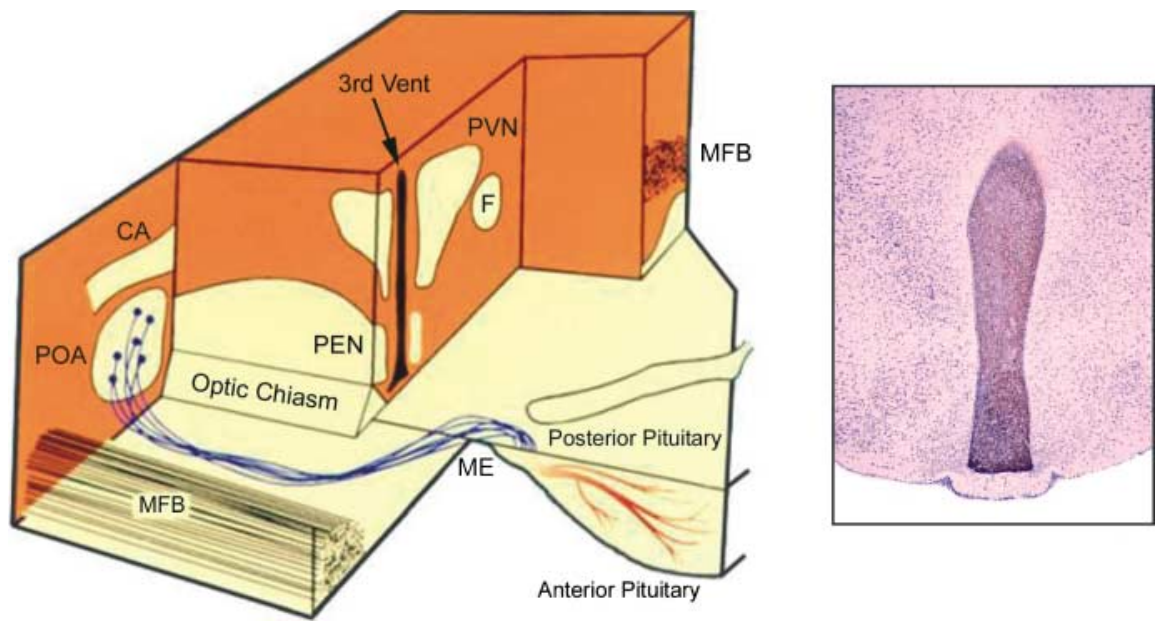

Figure 4 Diagrammatic representation of the hypothalamus, median eminence, third ventricle and pituitary gland. On the left, the figure demonstrates GnRH cell bodies in the preoptic area (POA) sending their axons to terminate in the median eminence (ME). The third ventricle is shaded black and is the site into which neural grafts are placed. The inset shows a healthy graft occupying the space of the third ventricle. The outpushing of the median eminence is obvious at the bottom of the micrograph. CA, anterior commisure; MFB, medial fore-brain bundle; PVN, paraventricular nucleus; PEN, periventricular nucleus; F, fornix. 

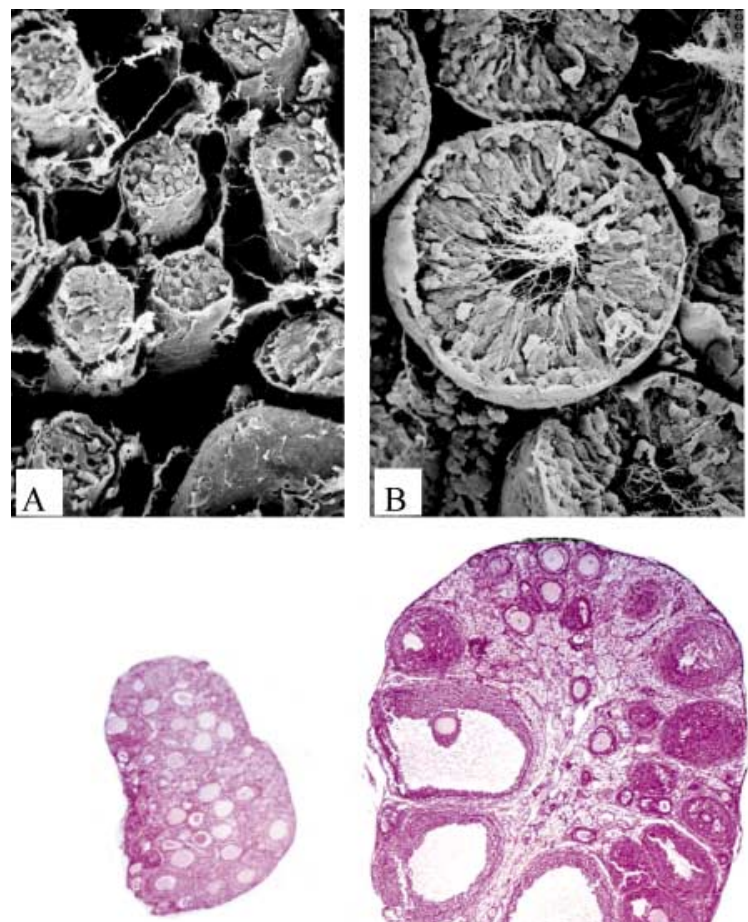

C

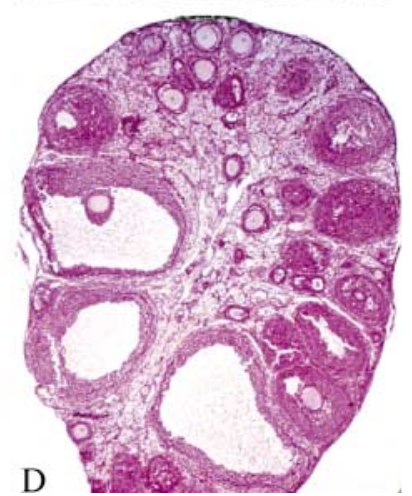

Figure 5 The effect of POA transplants upon the gonads of hpg mice. (A) Scanning electron micrograph of part of the testis of an adult hpg male. Note the small diameter of the seminiferous tubules and the absence of a central lumen. (B) Scanning electron micrograph, at the same magnification as (A), of part of the testis of an hpg male who received a neural graft of POA tissue from a post-natal day 1 mouse. Note the development of full spermatogenesis and the increased tubule diameter. (C) Photomicrograph of a section through the ovary of an adult female hpg mouse. Note the lack of mature follicles. (D) Section of an ovary, at the same magnification as (C), of an adult hpg female given a POA graft. Note the development of mature follicles but the absence of corpora lutea.

immunocytochemical examination indicated that $\mathrm{GnRH}$ neurones were present within the grafts and axon terminals reached the portal vessels draining the median eminence to the anterior pituitary gland (see Fig. 6).

Fibre outgrowth to the median eminence from POA grafts has been observed as early as 10 days post implantation. At this time there was little evidence of increased pituitary gonadotrophic content or of increased seminal vesicle weight in male hpg/POA mice. Between 26 and 40 days post grafting pituitary concentrations of gonadotrophic hormones were significantly elevated. Testicular growth was evident at 30 days in $94 \%$ of grafted males in one study (Silverman et al. 1985). The growth plateaued at around 90 days, with significant stimulation of the seminal vesicles in all recipients.

The results of POA grafts in hpg female mice were equally dramatic (Gibson et al. 1984a). In the majority of hpg female mice bearing hypothalamic transplants, vaginal opening occurred about 23 days after implantation and these animals displayed prolonged periods of oestrus as measured by vaginal smears. Pituitary gonadotrophic hormone content was normal but GnRH receptor concentrations only reached $60 \%$ of normal values. Within the ovaries LH receptors increased nearly 100-fold (Young et al. 1985).

The physiological actions of the grafts were not affected by the sex of the donor tissue, male or female POA tissue being equally effective. Control grafts of cortical tissue have been uniformly negative with regard to pituitary and gonadal stimulation in hpg mice.

Histological examination of the ovaries of positively responding females (i.e. those with vaginal opening and uterine stimulation) demonstrated the presence of developing and mature follicles but the absence of corpora lutea (see Fig. 5C and D), indicating that a spontaneous $\mathrm{LH}$ surge was not being produced. The presence of cornified cells in the vaginal smears and the stimulation of uterine growth in positive reproducing females were indications of steroid production by the ovaries. Female hpg mice treated with ovarian steroids display mating behaviour (Ward \& Charlton 1981) and it was anticipated that those female mutants with a physiological response to POA grafts would mate with normal male mice. Indeed, nine out of ten females with oestrous smears mated with the male on the first night of pairing. The remaining female mated on the second night. However, what was surprising was that seven out of these ten mice became pregnant and this reflex ovulation has been observed many times over the last few years (Gibson et al. 1984b).

This phenomenon of reflex ovulation has been described in female rats kept under conditions of constant light for long periods. They display persistent vaginal oestrus and ovulate in response to copulation (Brown-Grant et al. 1973).

What might be the normal substrate for the phenomenon of reflex ovulation in hpg females with third ventricular grafts of normal POA tissue? Although normal rats and mice are spontaneous ovulators, the activation of the corpus luteum to secrete progesterone depends upon a mating-induced release of prolactin, indicating that pathways exist whereby the reflex release of factors from nerve terminals in the median eminence are involved in prolactin release (Gunnet \& Freeman 1983). There is no reason to suppose that this system is not present within the brains of hpg mice.

It is difficult to envisage that the processes involved in pathway finding and axon guidance leading to a normal input to the $\mathrm{GnRH}$ cell body within fetal/neonatal tissue that has been dissected out and removed from its normal location and grafted to the third ventricle would be present in the grafted hpg adult. The evidence for an extensive and direct input of nerve fibres from the host into the grafts is far from robust (Silverman et al. 1992b).

However, in hpg/POA females that ovulate reflexly there is always evidence of $\mathrm{GnRH}$ fibres reaching the median eminence. This is irrespective of the random distribution of $\mathrm{GnRH}$ cell bodies within grafts. 

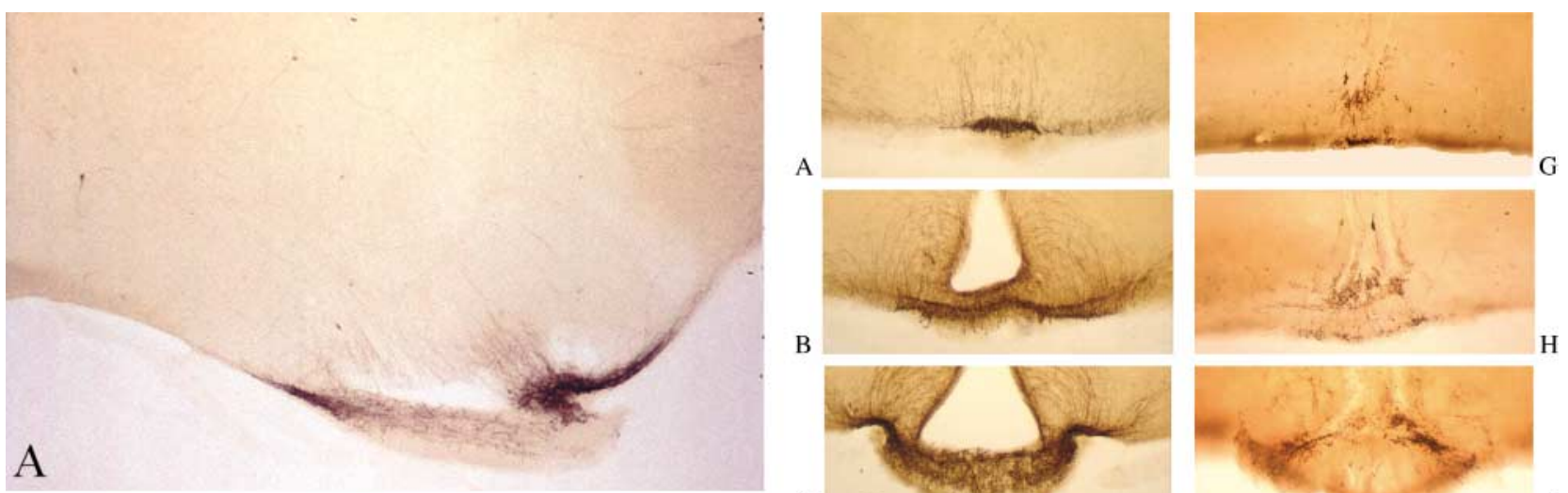

A
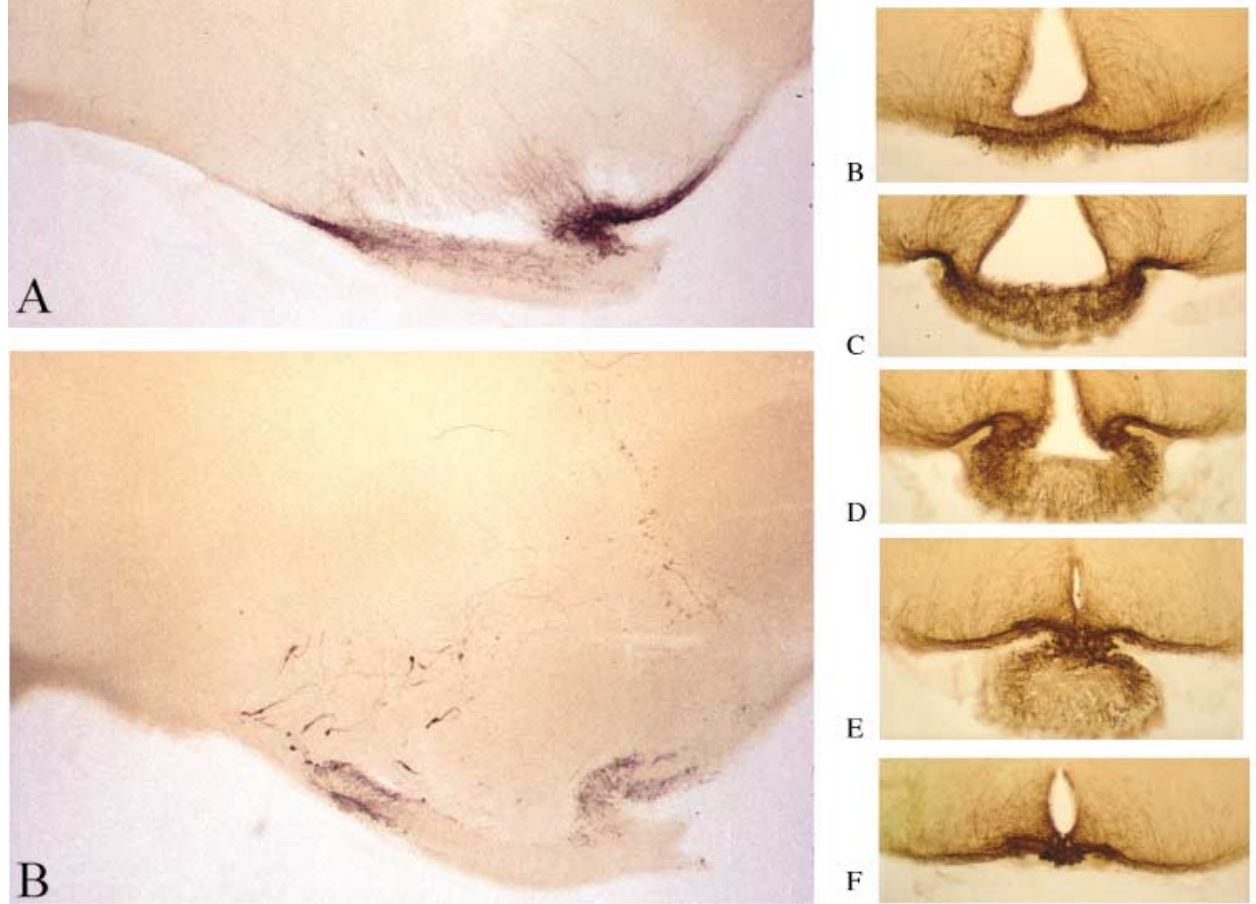
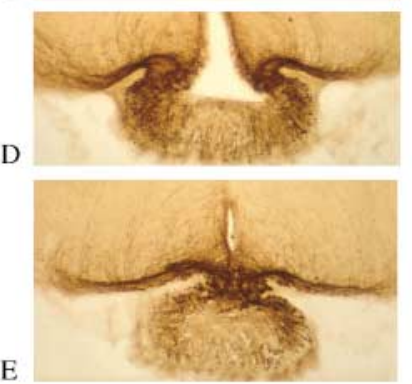

$\mathrm{F}$

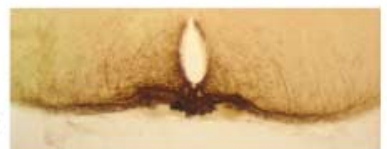

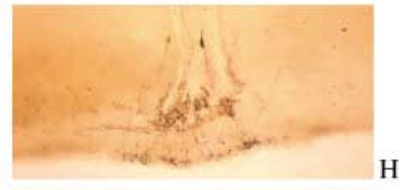

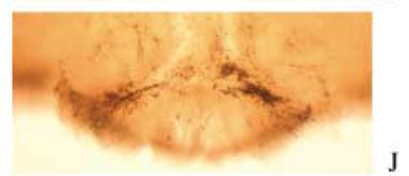

J

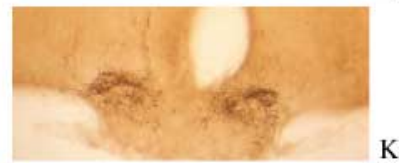

K
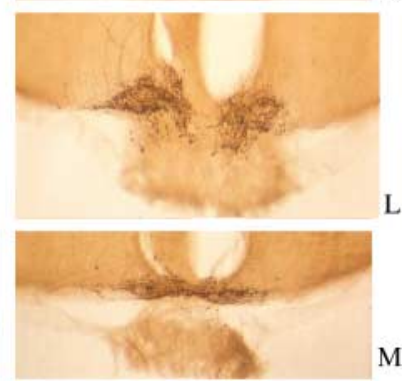

Figure 6 (Left panel) GnRH fibre distribution at the level of the hypothalamus in normal and hpg mice with a POA transplant. The two micrographs are of sagittal sections through the brain at the level of the hypothalamus and pituitary stalk, seen at bottom right. (A) The distribution of GnRH nerve terminals at this site in a normal mouse and (B) the exact mirroring of GnRH innervation of the median eminence/pituitary stalk from a third ventricular POA transplant in an hpg mutant are shown. (Right panel) A comparison of hypothalamic innervation by GnRH axons in normal and POA/hpg mice. This is a series of coronal sections from just behind the optic chiasm to the pituitary stalk comparing GnRH innervation in the normal mouse (A-F) with that in an hpg mouse with a POA graft (G-M). Note the specific input of nerve terminals from the graft.

Perhaps the most parsimonious explanation for reflex ovulation is that axo-axonic contacts from fibres involved in controlling prolactin release within the median eminence might elicit, in some bystander fashion, secretion of $\mathrm{GnRH}$ from nerve endings from the graft. For example it has been suggested that catecholaminergic terminals close to $\mathrm{GnRH}$ and endorphin-containing terminals within the median eminence itself could mediate some of the actions of opioid peptides upon $\mathrm{GnRH}$ release (Rasmussen et al. 1988). Similarly, Gambacciani et al. (1986) have suggested that oxytocin can inhibit in vitro release of $\mathrm{GnRH}$ by a receptor mechanism operating at the level of neurosecretory terminals in the median eminence.

There is also immunocytochemical evidence of an extensive overlap of catecholaminergic and $\mathrm{GnRH}$ varicosities within the median eminence (McNeill et al. 1980) and of considerable overlap in the distribution of $\mathrm{GnRH}$, tyrosine hydroxylase and glutamic acid decarboxylase fibres within the median eminence (Jennes et al. 1983), suggesting that dopamine and $\gamma$-aminobutyric acidergic neurones (GABA) can influence $\mathrm{GnRH}$ secretion via axoaxonic interactions at this site. Several other mechanisms are mentioned in the review of Kalra et al. (1997).
There is also evidence that glial-neuronal-endothelial interactions are part of a cell-cell communication system separate from transynaptic mechanisms in the control of GnRH secretion (King \& Rubin 1995, Prevot 2002, Zwain et al. 2002). The relationship between glial elements and axon terminals from POA grafts has been reported (Silverman et al. 1991). GnRH axons were found adjacent to glial elements along their entire traverse from the grafthost interface, through the host basal hypothalamus to their termination on the hypophysial portal capillaries.

Whilst this reviewer considers that the main conduit for reflex ovulation in hpg/POA females is likely to be via median eminence axo-axonic contacts, this is not to say that there are no fibres crossing from the host brain to the body of the grafts themselves. Evidence for this will be discussed below in the section Neurobiology.

\section{Pattern of hormone release induced by $\mathrm{GnRH}$ grafts}

Gibson et al. (1987) demonstrated that mating induced a significant rise in plasma $\mathrm{LH}$ in hpg/POA females within $10 \mathrm{~min}$ of ejaculation by the male, falling to baseline by 
$30 \mathrm{~min}$. Although the post-copulatory levels of LH were a fifth of those measured at the time of the pro-oestrous surge in normal mice they were sufficient to induce ovulation.

$\mathrm{GnRH}$ is considered to be released in a pulsatile manner with alterations in pulse frequency having important physiological consequences (Moenter et al. 2003). Immortalised GnRH neurones have been reported to exhibit synchronous bursts of electrical activity in vitro (Funabashi et al. 2001). Kokoris et al. (1988) were able to detect LH pulses in hpg/POA male mice. In ovariectomised normal females and ovariectomised hpg/POA females, blood sampling via a cardiac catheter with samples taken every 10 min for $4 \mathrm{~h}$ demonstrated significant $\mathrm{LH}$ pulses in nine out of ten normal mice and in nine out of thirteen hpg/POA females (Gibson et al. 1991). These experiments indicate that preoptic area grafts are capable of supporting episodic $\mathrm{LH}$ release and that there could be a functional $\mathrm{GnRH}$ pulse generator in mutant mice with grafts. The inability to detect $\mathrm{LH}$ pulses in all positive grafted females could be explained by technical difficulties.

Gibson et al. (1994) implanted osmotic mini-pumps into hpg mice delivering a constant infusion of GnRH subcutaneously. This elicited a dramatic and rapid increase in ovarian and uterine weight within 15 days. It is clear that gonadal growth in hpg/POA mice does not necessarily depend absolutely on a pulsatile pattern of $\mathrm{GnRH}$ release from the grafts.

\section{Steroid feedback in hpg/POA mice}

In wild-type male mice castration results in an elevation of plasma $\mathrm{LH}$ and a reduction in pituitary content of both $\mathrm{LH}$ and FSH. Subcutaneous implants of testosterone capsules for 10 days reduced pituitary $\mathrm{GnRH}$ receptor numbers and pituitary $\mathrm{LH}$ and $\mathrm{FSH}$ content, and induced a $50 \%$ reduction in testicular $\mathrm{LH}$ receptors. In positively responding hpg male mice bearing POA grafts neither castration nor testosterone capsules affected pituitary gonadotrophic hormone content (Charlton et al. 1987a). These experiments suggest that neither the pituitary gonadotroph nor the GnRH neurone represent major sites for the negative feedback of testosterone upon gonadotrophic hormone secretion in male mice. Gibson \& Silverman (1989) extended this work to female hpg/POA mice and reported a failure of negative feedback of oestradiol benzoate in most of the mice tested.

Gibson et al. (1988) investigated the possibility that ovarian steroid positive feedback mechanisms could result in $\mathrm{LH}$ surges in hpg/POA females and found that $25 \%$ of females treated with progesterone 2 months after grafting showed increased levels of $\mathrm{LH}$, but only $10 \%$ showed increased levels when animals were tested at 5 months. Sequential treatment of oestradiol benzoate and progesterone was ineffective in elevating $\mathrm{LH}$. The presence of corpora lutea in the ovaries confirmed that only those animals given progesterone ovulated. In this paper they reported the intriguing observation that a female hpg/POA mouse having mated twice, and then isolated after weaning of the second litter, displayed ovarian cyclicity and had corpora lutea in the ovaries.

Any positive feedback of ovarian steroids in stimulating $\mathrm{LH}$ release in physiologically active hpg/POA females could be explained by an effect upon the pituitary gland increasing gonadotroph sensitivity to a more constant $\mathrm{GnRH}$ input rather than the production of a surge of the decapeptide itself being released in the portal vessels. Naik et al. (1985) have shown that the pituitary can be a site of gonadal steroid stimulation of $\mathrm{GnRH}$ receptors in female mice. In the very rare case of apparent spontaneous ovulation it could also be possible that steroid feedback has sensitised the anterior pituitary sufficiently to elicit LH release without there necessarily being a $\mathrm{GnRH}$ surge.

\section{Transplantation of non POA GnRH neurones, or cell lines}

GT-1 is an immortalised cell line synthesising and secreting GnRH (Weiner et al. 1992). Grafting of this tumour cell line into hpg mutants demonstrated that the cells migrated widely within the brain and in many cases stimulated gonadal growth in both sexes. The greatest growth was found in animals in which tumours or axons were present in the region of the median eminence. In the other positive responders it is possible that large quantities of $\mathrm{GnRH}$ peptide reached the portal vessels and pituitary by diffusion (Silverman et al. 1992a). The migration of $\mathrm{GnRH}$ neurones from the nasal placode into the brain during prenatal development has been mentioned above. Livne et al. (1992) placed grafts of embryonic nasal septum containing GnRH neurones into the anterior hypothalamic area and preoptic area of adult male hpg mice. In half of the experimental animals there was evidence of testicular growth with GnRH fibres extending to the median eminence.

$\mathrm{GnRH}$ neurones are also found in the accessory olfactory bulb $(\mathrm{AOB})$, a site which does not normally innervate the median eminence. Perlow et al. (1987) transplanted fetal AOB tissue into the third ventricle of hpg mice with stimulation of pituitary gonadotrophic hormone synthesis and secretion and gonadal growth in 25\% of grafted recipients. In all positive mice $\mathrm{GnRH}$ axons innervated the median eminence.

\section{Neurobiology}

The physiological effects of POA grafts in male and female mice have proved to be robust and repeatable. Only when axon terminals innervate the median eminence are there signs of increased gonadotrophic hormone synthesis and secretion and gonadal stimulation. When POA tissue is transplanted into the lateral ventricle, $\mathrm{GnRH}$ neurones 
survive and extend processes into the host brain but never to the median eminence (Kokoris et al. 1987). What might be responsible for this specific innervation? The most plausible explanation is that the median eminence releases diffusible substances directing this outgrowth.

In a series of elegant experiments, Saitoh et al. (1992) co-grafted POA tissue either with anterior pituitary tissue or with a fetal hypothalamic block containing the median eminence. In pituitary co-grafts $\mathrm{GnRH}$ axon terminals entered the tissue, but also projected to the host median eminence. With the hypothalamic block the engrafted POA cells formed a mini-median eminence with a highly organised and robust GnRH innervation. In hypophysectomised hpg mice GnRH axons from POA grafts still projected to the median eminence, suggesting that the bulk of the pituitary gland was not essential for this specificity. Evidence for a diffusible chemoattractant factor has been provided in experiments in vitro in which $\mathrm{GnRH}$ axons target mediobasal hypothalamic blocks (Rogers et al. 1997). It must be remembered that the pars tuberalis of the anterior pituitary is closely adherent to the median eminence and could provide part of the guidance cues.

Neurones within the arcuate nucleus do not appear to play a role in directing axons to the median eminence because in hpg mice in which these cells have been destroyed by neonatal exposure to monosodium glutamate (Olney 1969) the normal pattern of $\mathrm{GnRH}$ innervation by grafts is maintained (Silverman et al. 1990).

Preoptic area grafts placed in the region of the mammillary body, which never contains GnRH cell bodies, but is nevertheless close to the median eminence, resulted in correct $\mathrm{GnRH}$ innervation and gonadal development. This supports the hypothesis that the median eminence releases diffusible substances directing GnRH outgrowth (Rogers et al. 1998).

The degree of input from the host brain into the body of the graft is more imponderable. Direct tracing methods using a fluorescent dye indicated that host innervation exists, but is limited in nature (Silverman et al. 1992b).

Intracellular recordings from neurones within POA grafts in brain slice preparations also indicated that there must be some input into the graft from the host (Hodgkiss \& Kelly 1990). However, whether or not this represents attempts by the host brain to wire graft GnRH neurones into specific and physiologically relevant circuits remains unanswered.

It has been reported that there is an increased synaptic input onto GnRH cell bodies within grafts in hpg/POA female positive responders using immunocytochemistry for the presynaptic marker, synaptophysin (Rajendren \& Gibson 2001). Galanin synapses were also increased on GnRH neurones within the grafts of mutant females exhibiting ovarian development (Rajendren 2002).

By definition, the physiologically activated hpg females will be secreting oestrogen from their ovaries. Matsumoto et al. (1988) have demonstrated that oestrogen stimulation of ovariectomised rats bearing preoptic area third ventricular grafts elicits a significant increase in axodendritic and spine synapses on neurones within the grafts. The question remains to be answered as to whether or not increased synaptic input is from host neurones or from oestrogen-stimulated interneurones within the grafts. It really is a chicken and egg situation - does the increased synaptic input into $\mathrm{GnRH}$ neurones result in a greater output of gonadotrophic hormones and therefore of ovarian oestrogen, or is the increase in synapses a consequence of elevated gonadal stimulation? Oestradiol concentrating cells are present within transplants in estimated numbers ranging from 390 to 2600 (Gibson et al. 1989). The methodology used in these experiments did not allow for any specific relationship between $\mathrm{GnRH}$ cells and those taking up oestrogen, but the possibility remains that a direct action of oestrogen upon interneurones or glial elements within the graft could provide a partial explanation for increased synaptic input into transplanted GnRH neurones.

The appearance of immunoreactivity to the transcription factor FOS in several GnRH cells following mating of hpg/POA females has been reported (Wu et al. 1996). This has been claimed to indicate the establishment of neuronal projections carrying somatosensory information to these cells. Again, the argument can be put forward that activation of $\mathrm{GnRH}$ nerve terminals in the median eminence via axo-axonic contacts could result in electrical events leading to exocytosis of granules from graft neurone terminals and a stimulation of the cell body, a consequence of which could be increased FOS gene transcription.

Saitoh et al. (1991), investigating the effects of N-methyl-D, L-aspartic acid on LH secretion, concluded that oestradiol was acting at the level of the pituitary in hpg/POA females. In experiments aimed at investigating potential neuromodulation of $\mathrm{GnRH}$ neurones in grafts, Miller et al. (1995) showed that $\beta$ endorphin-positive axons were present within the transplants but that there were no cell bodies. However, similar fibres were also found within the median eminence in the vicinity of the outgrowth of $\mathrm{GnRH}$ axons from grafts. There can be no doubt that host fibres cross the ventricular wall to enter grafted tissue, but it is difficult to state categorically that a drug or hormone treatment is specific to a particular host pathway directly connected to $\mathrm{GnRH}$ neurones in a graft. Activation could also be at other sites, including the pituitary gland or even via the blood stream supplying the transplants or the cerebrospinal fluid bathing them.

\section{Graft survival}

The age of the grafted POA tissue is crucial to the survival and function of grafts. Grafting embryonic tissue (embryonic days 16-18) resulted in 69\% of positive responders within 30 days. Post-natal day 1 (P1) tissue 
was equally successful whereas P5 tissue elicited positive physiological responses in only $22 \%$ of recipients. Tissue from P10 neonatal donors failed to survive (Charlton et al. 1987b).

The hpg colonies are not inbred, yet there is excellent survival of grafted tissue demonstrating the relative immune privilege within the CNS. The immunology of graft survival has been extended to demonstrate that, by depleting helper and cytotoxic T-lymphocytes using monoclonal antibodies, the hpg phenotype can be reversed with grafts of rat POA tissue. With two courses of treatment, one at the time of grafting and the other at 30 days, survival of the rat tissue was extended for months (Wood et al. 1998).

\section{Future perspectives}

The physiological effects of POA grafts in hpg mice have been extensively reported particularly from the laboratories of Marie Gibson and Anne-Judith Silverman. What has been difficult to determine is to what extent the host brain interacts with the donor tissue, and with what specificity.

With the advent of transgenic technologies it should be possible further to investigate this aspect of neural grafting. Selected strains of transgenic mice are available in which reporter genes have been targeted to specific neuronal populations. The bacterial enzyme $\beta$ galactosidase ( $\beta$-gal) has the advantage that not only can the enzyme convert the $\mathrm{x}$-gal substrate into a blue product in fixed tissues, there are also good antibodies and in situ hybridisation probes available to identify cells. It is also possible to identify living cells by fluorescent conversion of the $\mathrm{x}$-gal product (Herbison et al. 2001).

Green fluorescent protein (GFP) has also been targeted to $\mathrm{GnRH}$ neurones in transgenic mice, allowing easy visualisation of the cells both in living slices and in fixed tissue. Antibodies are also available for more permanent preparations (Spergel et al. 2001). Grafting POA tissue from such GFP (or $\beta$-gal) transgenics will allow more precise electrophysiological studies of $\mathrm{GnRH}$ neurones and their responses to hormones, drugs and neurotransmitters within grafts included in tissue slices. These responses can then be compared with those of reporter/GnRH neurones from normal animals.

Transgenic mice are also available in which there is a global production of the reporter gene products, GFP and $\beta$-gal. It would be possible to breed the hpg mutation onto these backgrounds; thus by grafting GFP neurones to hpg $\beta$-gal hosts (or vice versa) it would be possible to have a host brain expressing a different transgene from the donor GnRH reporter construct. Any fibres crossing into the graft would theoretically be readily detectable and, with advances in confocal microscopy, could provide a more robust measure of host-graft interactions.
For those working in the field of seasonal breeding it might be of interest to see whether or not POA grafts can maintain gonadal stimulation even in daylengths normally associated with an inhibition of reproductive function.

\section{References}

Brown-Grant K, Davidson JM \& Greig F 1973 Induced ovulation in albino rats exposed to constant light. Journal of Endocrinology $\mathbf{5 7}$ $7-22$.

Cattanach BM, Iddon CA, Charlton HM, Chiappa SA \& Fink G 1977 Gonadotrophin-releasing hormone deficiency in a mutant mouse. Nature 269 338-340.

Charlton HM, Halpin DM, Iddon C, Rosie R, Levy G, McDowell IF, Megson A, Morris JF, Bramwell A, Speight A, Ward BJ, Broadhead J, Davey-Smith G \& Fink G 1983 The effects of daily administration of single and multiple injections of gonadotropin-releasing hormone on pituitary and gonadal function in the hypogonadal (hpg) mouse. Endocrinology 113 535-544.

Charlton HM, Jones AJ, Ward BJ, Detta A \& Clayton RN 1987a Effects of castration or testosterone implants upon pituitary function in hypogonadal mice bearing normal foetal preoptic area grafts. Neuroendocrinology 45 376-380.

Charlton HM, Jones AJ, Whitworth D, Gibson MJ \& Kokoris G $1987 b$ The effects of the age of intracerebroventricular grafts of normal preoptic area tissue upon pituitary and gonadal function in hypogonadal (hpg) mice. Neuroscience 21 175-181.

Ebling FJ \& Cronin AS 2000 The neurobiology of reproductive development. Neuroreport 11 R23-R33.

Everett JW 1994 Pituitary and hypothalamus: perspectives and overview. In The Physiology of Reproduction, pp 1509-1526. Eds E Knobil \& JD Neill. New York: Raven Press Ltd.

Funabashi T, Suyama K, Uemura T, Hirose $M$, Hirahara F \& Kimura F 2001 Immortalized gonadotropin-releasing hormone neurons (GTI-7 cells) exhibit synchronous bursts of action potentials. Neuroendocrinology 73 157-165.

Gambacciani M, Yen SS \& Rasmussen DD 1986 GnRH release from the mediobasal hypothalamus. In vitro regulation by oxytocin. Neuroendocrinology 42 181-183.

Gibson MJ \& Silverman AJ 1989 Effects of gonadectomy and treatment with gonadal steroids and luteinizing hormone secretion in hypogonadal male and female mice with preoptic area implants. Endocrinology 125 1525-1532.

Gibson MJ, Charlton HM, Perlow MJ, Zimmerman EA, Davies TF \& Krieger DT 1984a Preoptic area brain grafts in hypogonadal (hpg) female mice abolish effects of congenital hypothalamic gonadotrophin-releasing hormone $(\mathrm{GnRH})$ deficiency. Endocrinology 114 1938-1940.

Gibson MJ, Krieger DT, Charlton HM, Zimmerman EA, Silvermann AJ \& Perlow MJ 1984b Mating and pregnancy can occur in genetically hypogonadal mice with preoptic area brain grafts. Science 225 949-951.

Gibson MJ, Moscovitz HC, Kokoris GJ \& Silverman AJ 1987 Plasma $\mathrm{LH}$ rises rapidly following mating in hypogonadal female mice with preoptic area (POA) brain grafts. Brain Research 424 $133-138$.

Gibson MJ, Kokoris GJ \& Silverman AJ 1988 Positive feedback in hypogonadal female mice with preoptic area brain transplants. Neuroendocrinology 48 112-119.

Gibson MJ, Silverman AJ, Rosenthal MF \& Morrell JI 1989 Estradiolconcentrating cells in the brains of hypogonadal female mice and in their intraventricular preoptic area implants. Experimental Neurobiology 105 127-134.

Gibson MJ, Miller GM \& Silverman AJ 1991 Pulsatile luteinizing hormone secretion in normal female mice and in hypogonadal female mice with preoptic area implants. Endocrinology 128 965-971. 
Gibson MJ, Kasowski H \& Dobrjansky A 1994 Continuous gonadotropin-releasing hormone infusion stimulates dramatic gonadal development in hypogonadal female mice. Biology of Reproduction 50 680-685.

Gunnet JW \& Freeman ME 1983 The mating induced release of prolactin: a unique neuroendocrine response. Endocrine Reviews 4 $44-61$.

Harris GW 1972 Humours and hormones, the Sir Henry Dale Lecture for 1971. Journal of Endocrinology 53 2-23.

Herbison AE 1998 Multimodal influence of estrogen upon gonadotropin-releasing hormone neurons. Endocrine Reviews 19 302-330.

Herbison AE, Pape JR, Simonian SX, Skynner MJ \& Sim JA 2001 Molecular and cellular properties of $\mathrm{GnRH}$ neurons revealed through transgenics in the mouse. Molecular and Cellular Endocrinology 185 185-194.

Hodgkiss JP \& Kelly JS 1990 An intracellular study of grafted and in situ preoptic area neurones in brain slices from normal and hypogonadal mice. Journal of Physiology 423 111-135.

Jennes L, Stumpf WE \& Tappaz ML 1983 Anatomical relationships of dopaminergic and GABAergic systems with the GnRH-systems in the septo-hypothalamic area. Immunohistochemical studies. Experimental Brain Research 50 91-99.

Kalra SP, Horvath T, Naftolin F, Xu B, Pu S \& Kalra PS 1997 The interactive language of the hypothalamus for the gonadotrophin releasing hormone $(\mathrm{GNRH})$. Journal of Neuroendocrinology 9 569-576.

King JC \& Rubin BS 1995 Dynamic alterations in luteinising hormone releasing hormone (LHRH) neuronal cell bodies and terminals of adult rats. Cell Molecular Neurobiology 15 89-106.

Kokoris GJ, Silverman AJ, Zimmerman EA, Perlow MJ \& Gibson MJ 1987 Implantation of fetal preoptic area into the lateral ventricle of adult hypogonadal mutant mice: the pattern of gonadotropinreleasing hormone axonal outgrowth into the host brain. Neuroscience 22 159-167.

Kokoris GJ, Lam NY, Ferin M, Silverman AJ \& Gibson MJ 1988 Transplanted gonadotropin-releasing hormone neurons promote pulsatile luteinizing hormone secretion in congenitally hypogonadal (hpg) male mice. Neuroendocrinology 48 45-52.

Krieger DT, Perlow MJ, Gibson MJ, Davies TF, Zimmerman EA, Ferin M \& Charlton HM 1982 Brain grafts reverse hypogonadism of gonadotrophin releasing hormone deficiency. Nature $\mathbf{2 9 8}$ $468-471$.

Livne I, Gibson MJ \& Silverman AJ 1992 Brain grafts of migratory $\mathrm{GnRH}$ cells induce gonadal recovery in hypogonadal (hpg) mice. Developmental Brain Research 69 117-123.

McNeill TH, Scott DE \& Sladek JR Jr 1980 Simultaneous monoamine histofluorescence and neuropeptide immunocytochemistry. Localisation of catecholamines and gonadotropin-releasing hormone in the rat median eminence. Peptides 159-68.

Mason AJ, Hayflick JS, Zoeller RT, Young WS, Phillips HS, Nikolics K \& Seeberg PH 1986a A deletion truncating the gonadotropinreleasing hormone gene is responsible for hypogonadism in the hpg mouse. Science 234 1366-1371.

Mason AJ, Pitts SL, Nikolics K, Szonyi E, Wilcox JN, Seeberg PH \& Stewart TA $1986 b$ The hypogonadal mouse: reproductive functions restored by gene therapy. Science 234 1372-1378.

Matsumoto A, Murakami S \& Arai Y 1988 Neurotropic effects of oestrogen on the neonatal preoptic area grafted into the adult rat brain. Cell Tissue Research 252 33-37.

Miller GM, Silverman AJ, Rogers MC \& Gibson MJ 1995 Neuromodulation of transplanted gonadotropin-releasing hormone neurones in male and female hypogonadal mice with preoptic area brain grafts. Biology of Reproduction 52 572-583.

Moenter SM, DeFazio AR \& Pitts GR 2003 Mechanisms underlying episodic gonadotropin-releasing hormone secretion. Frontiers in Neuroendocrinology 24 79-93.
Naik SI, Young LS, Charlton HM \& Clayton RN 1985 Evidence for a pituitary site of gonadal steroid stimulation of GnRH receptors in female mice. Journal of Reproduction and Fertility 74 615-624.

Olney JW 1969 Brain lesions, obesity and other disturbances in mice treated with monosodium glutamate. Science 164 719-721.

Perlow MJ, Kokoris G, Gibson MJ, Silverman AJ, Krieger DT \& Zimmerman EA 1987 Accessory olfactory bulb transplants correct hypogonadism in mutant mice. Brain Research 415 158-162.

Prevot V 2002 Glial-neuronal-endothelial interactions are involved in the control of GnRH secretion. Journal of Neuroendocrinology 14 247-255.

Rajendren G 2002 Increased galanin synapses onto activated gonadotropin-releasing hormone neuronal cell bodies in normal female mice and in functional preoptic area grafts in hypogonadal mice. Journal of Neuroendocrinology 14 435-441.

Rajendren G \& Gibson MJ 2001 Increased synaptic input to gonadotropin releasing hormone cells in preoptic area grafts that support reproductive development in female hypogonadal mice. Journal of Neuroendocrinology 13 270-274.

Rasmussen DD, Kennedy BP, Ziegler MG \& Nett TM 1988 Endogenous opioid inhibition and facilitation of gonadotropin-releasing hormone release from the median eminence in vitro: potential role of catecholamines. Endocrinology 123 2916-2921.

Rogers MC, Silverman AJ \& Gibson MJ 1997 Gonadotropin-releasing hormone axons target the median eminence: in vitro evidence for diffusible chemoattractive signals from the mediobasal hypothalamus. Endocrinology 138 3956-3966.

Rogers MC, Silverman AJ \& Gibson MJ 1998 Preoptic area grafts implanted in mammillary bodies of hypogonadal mice: patterns of $\mathrm{GnRH}$ neuronal projections. Experimental Neurology 151 265-272.

Saitoh Y, Silverman AJ \& Gibson MJ 1991 Effects of N-methyl-D, L-aspartic acid on luteinizing hormone secretion in normal mice and in hypogonadal mice with foetal preoptic area implants. Endocrinology 128 2432-2440.

Saitoh Y, Gibson MJ \& Silverman AJ 1992 Targeting of gonadotropinreleasing hormone axons from preoptic area grafts to the median eminence. Journal of Neuroscience Research 33 379-391.

Silverman AJ, Zimmerman EA, Gibson MJ, Perlow MJ, Charlton HM, Kokoris GJ \& Krieger DT 1985 Implantation of normal fetal preoptic area into hypogonadal mutant mice: temporal relationships of the growth of gonadotropin-releasing hormone neurons and the development of the pituitary/testicular axis. Neuroscience $\mathbf{1 6}$ 69-84.

Silverman RC, Gibson MJ, Charlton HM \& Silverman AJ 1990 Are neurons of the arcuate nucleus necessary for path finding by $\mathrm{GnRH}$ fibres arising from third ventricular grafts? Experimental Neurology 109 204-213.

Silverman RC, Gibson MJ \& Silverman AJ 1991 Relationship of glia to $\mathrm{GnRH}$ axonal outgrowth from third ventricular grafts in hpg hosts. Experimental Neurology 114 259-274.

Silverman AJ, Roberts JL, Dong KW, Miller GM \& Gibson MJ 1992a Intrahypothalamic injection of a cell line secreting gonadotropinreleasing hormone results in cellular differentiation and reversal of hypogonadism in mutant mice. PNAS 89 10668-10672.

Silverman RC, Gibson MJ \& Silverman AJ 1992b Application of a fluorescent dye to study connectivity between third ventricular preoptic area grafts and host hypothalamus. Journal of Neuroscience Research 31 156-165.

Silverman AJ, Livne I \& Witkin JW 1994 The gonadotropin-releasing hormone $(\mathrm{GnRH})$, neuronal systems: immunocytochemistry and in situ hybridisation. In The Physiology of Reproduction, pp 16831709. Eds E Knobil \& JD Neill. New York: Raven Press Ltd.

Spergel DJ, Kruth U, Shimshek DR, Sprengel R \& Seeburg PH 2001 Using reporter genes to label selected neuronal populations in transgenic mice for gene promoter, anatomical and physiological studies. Neurobiology 63 673-686. 
Ward BJ \& Charlton HM 1981 Female sexual behaviour in the GnRH deficient, hypogonadal (hpg) mouse. Physiological Behaviour 27 1107-1109.

Weiner RI, Wetsel W, Goldsmith P, Martinez de la Escalera G, Windle J, Padula C, Choi A, Negro-Vilar A \& Mellon P 1992 Gonadotropin-releasing hormone neuronal cell lines. Frontiers in Neuroendocrinology 13 95-119.

Wood MJ, Wood KJ \& Charlton HM 1998 Long-term restoration of gonadal activity with xenografts of preoptic area tissue in hypogonadal (hpg) mice. Genetic Research 72 229-236.

Wray S 2002 Development of gonadotropin-releasing hormone-1 neurons. Frontiers in Neuroendocrinology 23 292-316.
Wu TJ, Silverman AJ \& Gibson MJ 1996 FOS expression in grafted gonadotropin-releasing hormone neurons in hypogonadal mouse: mating and steroid induction. Journal of Neurobiology 31 67-76.

Young LS, Detta A, Clayton RN, Jones A \& Charlton HM 1985 Pituitary and gonadal function in hypogonadotrophic hypogonadal (hpg) mice bearing hypothalamic implants. Journal of Reproduction and Fertility $\mathbf{7 4} 247-255$.

Zwain IH, Arroyo A, Amato P \& Yen SS 2002 A role for hypothalamic astrocytes in dehydroepiandrosterone and estradiol regulation of gonadotropin-releasing hormone $(\mathrm{GnRH})$ release by $\mathrm{GnRH}$ neurons. Neuroendocrinology 75 375-383. 